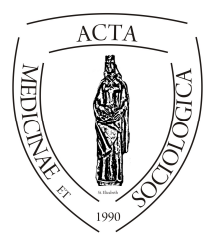

Acta Medicinae et

Sociologica (2019)

Vol. 10. No. 28.

DEBRECEN

FACULTY OF

HEALTH

doi:

\title{
Határmenti ifjúság gazdasági és társadalmi viszonyulása a térséghez
}

\author{
Ludescher Gabriella \\ főiskolai docens, Debreceni Egyetem Egészségügyi Kar. 4400 Nyíregyháza, Sóstói u. 2-4.
}

INFO

Ludescher Gabriella

ludescher.gabriella@foh.unideb

.hu

Keywords

border region, youth, territorial identity, cohesion

\section{ABSTRACT}

The Economic and Social Attitude of Young People to the Border Regions Where They Live. The study maps the North-Eastern European 17-19-year old young people living in the counties along the border in Poland, Ukraine and Hungary. The hypothesis of the research study is that the regional identity of the young people is in significant connection with their transborder economic, social activity. According to another research hypothesis those young people assess their attitude to the neighbouring nationalities ,very positively" who travel abroad more often and/or whose relatives are members of that nationality.

The regions selected to the research have special geographical endowments, however, they face serious economic and social difficulties as well. The competitiveness and prosperity of these regions more and more depend on whether the people and enterprises living there are able to optimally use all the territorial advantages. The competitiveness of the economy depends on the development of relationships with other territories, however, research studies have shown that current enterprises in this region could not live with the opportunities offered by the region's location, which can be explained by their postsocialist past (Hardi, 2001).

From the 1990s cross-border cooperation started to appear among the North-Eastern European regions. The 2004 EU accession made free movement of goods, services and capital possible for two countries (Hungary and Poland) from among the examined countries. In addition to this movement, the flow of technology and ideas as well as cross-border cooperation have become a more and more important element of the regional development.

The reason why the 17-19-year old age group has become the target group of the research study is that they were not 
only born into these new possibilities but they will also become a part of their daily lives. Hopefully during the next decade this age group will become the engine of the crossborder economy and cohesion due to their regional location and their relations.

Kulcsszavak
határmenti régió, ifjúság,
területi identitás, kohézió
területi identitás, kohézió
Absztrakt: A tanulmány Kelet-közép Európa három országának - Lengyelország, Ukrajna és Magyarország - egy-egy határmenti megyéjének ifjúságát (17-19 éves) kutatja. A kutatás hipotézise, hogy az ifjúságnak a területi identitása szignifikáns összefüggésben van határontúli gazdasági, társadalmi tevékenységével. Kutatási feltételezésként fogalmazódott meg az is, hogy azok a fiatalok értékelik a viszonyulásukat a szomszédos nemzetekkel „nagyon pozitívan”, akik gyakrabban utaznak külföldre, vagy/és rokoni kapcsolat füzi ahhoz a nemzethez. A tanulmány a hipotéziseit a következő kérdések mentén tárgyalja:

- a határmenti fiataloknak mi a véleményük a saját régiójúkban lévő lehetőségekről,

- mennyire érzik erősnek a kapcsolatukat, városukkal, megyéjükkel, régiójúkkal, Európával, illetve saját etnikai csoportjukkal.

- Továbbá a vizsgálat tárgya az is, hogy az adott határmenti térség, milyen hatással van a megkérdezettek életére, a szomszédos országokhoz milyen kapcsolat, illetve gazdasági tevékenység füzi a célcsoportot, valamint milyen gyakran szoktak külföldön járni és azt milyen célból teszik.

Kutatás fontos eleme volt a határmenti terület gazdasági és társadalmi hatásának mérésén túl az is, hogy a szomszédos nemzetekhez, milyen a viszonyulásuk a megkérdezetteknek. A vizsgálatra kiválasztott régiók különleges földrajzi adottságokkal rendelkező régiók, de emellett komoly gazdasági és társadalmi nehézségekkel küszködő térségek is. Ezen területek versenyképessége és jóléte egyre inkább attól függ, hogy az ott élő emberek és az ott élő vállalkozások optimálisan ki tudják-e használni valamennyi területi előnyt, mint például szomszédos ország gazdaság- és munkaerő- piacát, szolgáltatásokat, infrastruktúrát, valamint a nemzetközi kapcsolatokat. A gazdaság versenyképességének fejlődése függ más területekkel való kapcsolatok kiépítésétől. Az eddigi kutatások (Hardi, 2001) azt bizonyítják, hogy a jelenlegi vállalkozások a keleti térségben nem tudtak élni a régió elhelyezkedéséből fakadó lehetőségekkel. Ez magyarázható e térségek posztszocialista mivoltával is. Az 1990-as évektöl az észak-kelet európai régiókban határmenti együttmüködések kezdenek megjelenni, de a 2004-es Európai Uniós csatlakozás lehetővé teszi a vizsgált országok közül Magyarország és Lengyelország számára az áruk, a szolgáltatások és a tőke szabad mozgását. E mozgás mellett a technológia és az ötletek áramlása, valamint a határmenti kooperáció a területi 
fejlődés egyre fontosabb elemévé válik, megjelennek a komparatív előnyök is. A vizsgálati célcsoportként többek között azért választottuk a 17-19 éves korosztályt, mivel ök az új lehetőségekbe beleszülettek és azok a mindennapi életük részévé váltak. Remélhetőleg az elkövetkezendő tíz évben e korosztály tagjai a területi elhelyezkedésük és kapcsolataikból adódóan a határon átívelő gazdasági és társadalmi kohézió motorává válnak.

\section{Bevezetés ${ }^{1}$}

Az 1990-es évek óta végbement területi változások, mint például a határok szabad átjárása, a régiók felülről vezérelt „megszületése” és az Európai Unió közösségéhez való csatlakozás olyan változásokat hozott, melyek lassan beépültek az emberek mindennapi életébe. A társadalmunk fiatal korosztálya beleszületett e változásokba, így természetes számukra a régió fogalma és a határokon átívelő szabad mozgás. A kutatások (Egedy, 1996; Ristić - Nagy - Kicošev, 2013) azt bizonyítják, hogy fiatalok a településüket, a régiójúkat, az országukat, a szomszédos országokat és Európát elsősorban emocionális alapon élik meg és értékelik. A regionális tudomány szakirodalma (Somlyódiné Pfeil, 2007; Palkó, 2009; Murányi - Szoboszlai, 2000; Nárai 2009; Paasi, 1989; Ludescher 2009) több évtizede foglalkozik területi identitástudattal, lokalitás vizsgálatával. Ugyan az empirikus vizsgálatokban kis számban jelenik meg (Ristić - Nagy - Kicošev, 2013; Egedy, 1996) a fiatalok lokális identitástudatának vizsgálata. Sajnálatosan az ifjúságkutatásokban még kevesebb figyelmet fordítanak a fiatalok lokális területeikhez, régióikhoz kapcsolódó identitás vizsgálatára. Fontos lenne e témára a szakmának jobban fókuszálni, mert a különböző helyek és terek - amelyekben a fiatalok élnek, és amelyek körülveszik őket - befolyásolják, alakítják az identitásukat. A társadalmi terekkel foglalkozó elméletek többségének egyik alapvető feltevése, hogy a térbeliség a társadalmi tevékenység fontos dimenziója. A teret értelmezhetjük olyan kontextusként, amelyben a társadalmi élet zajlik, a tér ugyanakkor a társadalmi élet lenyomata is (Strassoldo 1990).

Jól ismert, hogy a határmenti települések sajátos település-földrajzi, gazdasági, kulturális, szociológiai, oktatási térségeket (Süli-Zakar, 2010) - gyakran perifériális helyzetü térséget (Ilyés, 2004) - alkotnak. Hardi definíciója szerint ,azt tekinthetjük határ menti térségnek, amelynek mindennapi életét alapvetően befolyásolják a szomszédos határtérséggel fenntartott interakciók" (Hardi, 2008:4). A határ menti régiókat ráadásul úgy is felfoghatjuk, mint egyfajta átmeneti szintet: egyrészről megszürik a globális jelenségeket a lokális színtér és az egyén számára, másrészt összegyüjti a lokális és individuális jelenségeket, folyamatokat, attitüdöket (Süli-Zakar, 2010).

\footnotetext{
${ }^{1}$ Jelen tanulmányt megelőzte ANON tanulmánya, mely a nyíregyházi fiatalokat mutatja be hasonló témakört körüljárva. E nemzetközi kutatás adatbázisa tartalmazza a nyíregyházi lekérdezés adatait így megegyezik a fent említett szerzők által e témában feldolgozott adatokkal.
} 
A határmenti identitás nem minden esetben van szoros viszonyban a politikai-állami identitás által kialakított határokkal, sok esetben nagyobb hatással lehetnek a regionális, kulturális identitások, azok területi elemei. Elmondhatjuk, hogy az egyes ember gondolkodásában egyre kisebb jelentőségűvé válik a nemzetállam határa, sokkal inkább a határtérség kerül előtérbe, mivel a kulturális identitásokon keresztül az egybefüggő területek válnak a gondolkodás keretévé (Hardi, 2001).

Éppen ezért lehet érdekes megvizsgálni, hogy ilyen sajátos, államhatárhoz közeli városok, mint például Nyíregyháza (Magyarország), Rzeszów (Lengyelország) és Ungvár (Ukrajna) fiataljaira (11-12. évfolyamos középiskolai diákjaira) mennyire jellemző a regionalitás, s hogy e diákok mennyire kötődnek lokális, regionális szinten, vagy éppen mennyire mobilisak regionális vagy nemzetközi szinten.

Így az elemzések első részében azt vizsgáljuk, hogy saját családjukhoz, országukhoz, városukhoz/falvaikhoz, megyéjükhöz, régiójukhoz és Európához hogyan viszonyulnak a fiatalok, mennyire erős a lokális identitástudatuk. Ebből következően a vizsgálatnak egyik fő kérdése, hogy az identitástudat mennyire határozza meg az életesélyeket, amit helyben látnak maguk számára. Nyilvánvalóan különösen meghatározó a lokális identitástudatunk tekintetében a területi hovatartozásunk. Bőhm (2000) vizsgálatai során azt állapította meg, hogy a magyar lakosság körében az 1990-es években a lokális identitás felerősödött, a megyei identitás gyengült, a regionális szinte nem létezett. Ami magyarázható azzal, hogy a régió, mint térség egy felülről való kezdeményezés és kialakulófélben volt.

Az identitás Csepeli (1997) szerint a nemzeti, vallási, nemi, generációs, világnézeti kategóriákat a szocializáció során sajátítjuk el. Ezt követően pedig magától értetődően alkalmazzuk öket önmagunk és mások társadalmi helyének megállapításakor. Funkciója az, hogy az egyén a közvetlen személyes tapasztalat világán túlmenően képes legyen elhelyezni önmagát az ismerősség és az idegenség dimenziója mentén. Kérdés az is, hogy a 17-18 éves korosztály tud-e mit kezdeni egyes térség típussal és beépül-e mint identitási tényező, valamint a felsorolt identitástípusok közül, mely dominál erősebben.

A legfiatalabb múlttal az identitások közül a regionális kötődés rendelkezik. Létezéséről is többféleképpen vélekednek, Nárai (2009) úgy gondolja, hogy a regionális identitás nem más, mint egy területi kötődés azaz „,személyiséget” kölcsönöz az adott térségnek. Paasi (2003) egy régió közös identitását abban látja, hogy társadalmi, területi, történelmi és kulturális gyökerekre nyúlik vissza. Raagmaa (2002) meglátása szerint a regionális identitás egyszerre tudatos és emocionális azonosulás, kötődés egy térséghez (régióhoz), amely történelmi és területi szocializációs folyamat eredményeként jön létre. Míg Blotevogel és szerzőtársai (1989) regionális identitás különböző szintjeit határozták meg. Első a kognitív szint régió identitása, azaz egy régió azonosíthatósága, a második az affektív (érzelmi) mint a személyes identitás szempontja jelenik meg. A harmadik a konatív szint, mint a szociális identitás szempontja jelenik meg - a régió az ott élők mi-tudatának szerves alkotóelemévé válik (kialakulásában meghatározó a régióval való elégedettség is). Megállapíthatjuk, hogy minden szemlélet szerint elfogadott a regionális identitás léte, csak a megragadásában és mérésében különbözik.

A tanulmány a külföldi tapasztalatokat és terveket, a lokális, regionális kötődést egymáshoz viszonyítva vizsgálja. Továbbá a külföldi mobilitási tapasztalatokra és 
tervekre koncentrál, valamint arra, hogy mennyire nyitottak jövőterveiket tekintve a külföldi tanulás, külföldi munkavállalás iránt. Az elemzések második része kitér arra, hogy a vizsgált fiatalok mennyit utaznak a határokat átlépve. Felmértük a nyitottságot, azaz a társadalmi távolságot a diákok szimpátiáján keresztül a szomszédos országok és más nemzetek iránt.

Ezek a kérdések napjainkban demográfiai okok miatt is jelentősek. Fontos megismernünk a fiatalság identitását, mind a lokális, mind az érzelmi kötödésüket, valamint a tervek és az identitás közötti összefüggések feltárása is meghatározó lehet az ifjúság megtartásában. A nagy mintás $(\mathrm{N}=8000)$ reprezentatív Magyar Ifjúság Kutatás 2016 (2017) is kitér a fiatalok munkavállalási szándékaira és a jövőtervezésükre. A magyarországi fiatalok kétharmada kizárólag Magyarországon képzeli el a jövőjét, egyharmaduk hosszabb-rövidebb ideig külföldön dolgozna vagy tanulna. A külföldi tervekkel rendelkezők ( $N=2632)$ 83\%-a egy pár évet szeretne külföldön dolgozni, 55\%-uk pár hétre vagy hónapra tervezi a külföldi munkát, 45\%-a külföldön szeretne letelepedni és 25\%-uk tanulni szeretne külföldön. Az országos kutatás a külföldi jövőtervekkel kapcsolatban regionális eltéréseket tapasztalt: míg a Nyugat-Dunántúlon élö fiatalok 40\%-a tervez valamilyen hosszabb-rövidebb külföldi tartózkodást, addig KözépMagyarországon ez az arány 26\%. Érdekes lenne megismerni, hogy ezen regionális különbségeknek a hátterében mi áll, valamint a többi régiókban milyen adatok születettek. E kérdésünkre a tanulmányból nem kapunk választ, viszont a Magyar Ifjúság Kutatás 2016 (2017) kitér arra, hogy azok a fiatalok, akik az itthon maradást választották, ezt milyen fő okokkal magyarázzák. Első leggyakoribb válaszként a családhoz való ragaszkodás (71\%) jelenik meg, másodikként a barátok $(51 \%)$ és a megkérdezettek közel fele $(45 \%)$ a haza szeretetét jelölte meg, mint visszatartó erő.

A kutatás során a családhoz való kötödés mellett a magyar identitástudat is erősen mutatkozik. A fiatalok alapvetően büszkék Magyarországra (42\%), nyelvükre, hazájuknak érzik (50\%) és szeretik az országukat (48\%) (Magyar Ifjúság Kutatás 2016).

\section{Kutatási módszertan}

A tanulmány egy nemzetközi kutatás kérdőíves vizsgálat adatait dolgozza fel. A vizsgálat egy nemzetközi projekt keretében valósult meg 2015-ben (Youth in the Central and Eastern European Crossborder Areas), melyben a lengyel, ukrán, magyar határ menti térség egy-egy nagyvárosban élő érettségi előtt álló középiskolás fiatalokat kérdeztek meg. A kiválasztott városok Magyarországon Nyíregyháza $(\mathrm{N}=359)$, Lengyelországban Rzeszów $(\mathrm{N}=413)$ és Ukrajnában Ungvár $(\mathrm{N}=468)$ volt. 


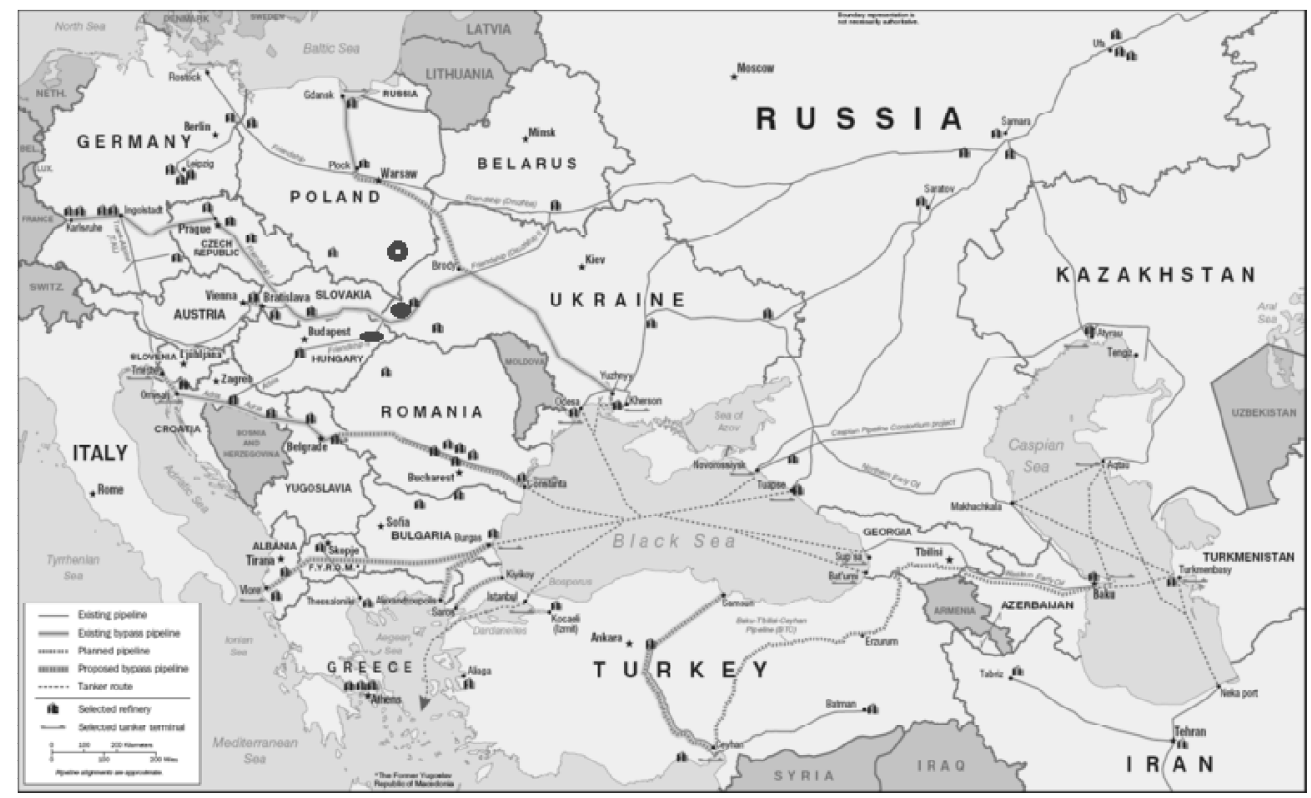

Forrás: https://de.m.wikipedia.org/wiki/Datei:Oil_pipelines_in_Europe.png (látogatva 2016. 12. 03.)

A vizsgálat során a lekérdezetteket $(\mathrm{N}=1240)$, mind gimnáziumból, mind szakközépiskolából választottuk ki, csoportos rétegzett mintavételt alkalmaztunk. A célcsoportot 668 nő és 535 férfi alkotta, 133 fö nem jelölte meg a nemét (a figyelmetlen kérdőív kitöltése lehet az oka). 63\%-uk városban és 35,8\%-uk vidéken lakik. A megkérdezettek édesapjuknak a következő százalékban oszlik meg az iskolai végzetségük: 11\%-nak alacsony, 60,3\%-nak közép és a 28,7\%-nak magas.

A ,Youth in the Central and Eastern European Crossborder Areas” kérdoíves vizsgálat célja, hogy feltárja a határmenti térségben élö fiatalok tanuláshoz, munkához kapcsolódó jövőképének, életcéljainak attitüdjeit. Megismerje a külföldhöz, a régiójukhoz kapcsolódó viszonyát és feltérképezze a fiatalok életmódjának és társadalmi hátterének elemeit. A jelen tanulmány tárgya a fent felsoroltaknál szükebb, mivel csupán a három ország fiataljainak a regionális, és a lokális kötődésének mérésére, valamint a fiatalok szomszédos országokkal kapcsolatos attitüdjeinek, gazdasági tevékenységeinek vizsgálatára tér ki.

A legfontosabb alapstatisztikák ismertetése után varianciaelemzéssel, regresszió és khí-négyzet próbával elemezzük a legfontosabb társadalmi háttérváltozók (ország, nem, lakóhely településtípusa, szülők iskolai végzettsége, munkaerő-piaci státusza és beosztása, szubjektív anyagi helyzet ${ }^{2}$ ) hatását a vizsgált kérdéskörökben.

${ }^{2}$ A szubjektív anyagi helyzet kérdése: Jelölje meg, az alábbiakban felsorolt válaszok közül melyik mutatja legjobban az Ön családja anyagi helyzetét? 1. Nagyon szegényen élünk, még az alapvetö szükségletekre sem jut elég pénz; 2. Szerényen élünk, minden napot ki kell gazdálkodni; 3. Közepesen élünk, elegendö pénzünk van a mindennapi szükségletekre, de drágább dolgokra már nem jut; 4. Elég jól élünk, jut mindenre; 5. Másokhoz viszonyítva mi nagyon jól élünk, luxus dolgokat vagy megtakarítást is megengedhetünk magunknak 


\section{Lokális és regionális identitás a fiataloknál}

Különböző lokális, nemzeti identitást vizsgáló kutatásokat áttekintve találtunk rá Ristić - Nagy - Kicošev (2013) kutatására. Vizsgálataik során megállapították, hogy a hely fogalmához gyakran kötődnek közösségekről alkotott elgondolások és képzetek, ugyanakkor a helyek nem jelentenek szükségszerüen közösségeket, habár elősegíthetik a közösség kialakulását. Ristić - Nagy - Kicošev, 2013-ban egy temerini (vajdasági) ${ }^{3}$ középiskolások körében végzett „hely” és identitás vizsgálatot. Zárt kérdést tettek fel azzal kapcsolatban, hogy legszívesebben hogyan értelmeznék magukat a diákok: európaiként, kelet-európaiként, szerbként vagy magyarként, esetleg temerininek, vajdaságinak tekintik identitásukat. Mind a szerb, mind a magyar diákok szemében az etnikai közösséghez tartozás jóval fontosabb, mint az egyéb, etnikailag vegyes közösségekhez (régió, település) való kötődés.

\begin{tabular}{|c|c|c|c|c|c|c|}
\hline & Országok & $\begin{array}{c}\text { Nagyon } \\
\text { erôs }\end{array}$ & Erös & Gyenge & $\begin{array}{c}\text { Egyáltalán } \\
\text { nem } \\
\text { érzem }\end{array}$ & $\begin{array}{c}\text { Nem tu- } \\
\text { dom/nem } \\
\text { válaszolok }\end{array}$ \\
\hline \multirow{3}{*}{$\begin{array}{l}\text { Országa } \\
\text { állampolgára- } \\
\text { ival }\end{array}$} & $\mathrm{HU}$ & 3,7 & 23,2 & 42,9 & 16,6 & 12,7 \\
\hline & PL & 20,9 & 46,8 & 26,6 & 37,1 & 0 \\
\hline & UA & 16,6 & 37,1 & 33,7 & 7,1 & 5,5 \\
\hline \multirow[t]{3}{*}{ Családdal } & $\mathrm{HU}$ & 63,3 & 29,1 & 5,9 & 0 & 1,7 \\
\hline & $\overline{\mathrm{PL}}$ & 63,7 & 29,5 & 5,4 & 1,5 & 0 \\
\hline & UA & 71,4 & 22,5 & 4,6 & 0,4 & 1,1 \\
\hline \multirow{3}{*}{$\begin{array}{l}\text { Városával } \\
\text { (falujával), } \\
\text { ahol él }\end{array}$} & $\mathrm{HU}$ & 7,3 & 35,3 & 40,3 & 10,4 & 6,7 \\
\hline & $\mathrm{PL}$ & 14,1 & 46,8 & 31,2 & 7,8 & 0 \\
\hline & UA & 16,1 & 39,8 & 35,9 & 5,5 & 2,8 \\
\hline \multirow[t]{3}{*}{ Megyéjével } & $\mathrm{HU}$ & 2,2 & 19,9 & 46,9 & 19,1 & 11,8 \\
\hline & PL & 3,7 & 15,2 & 58,4 & 22,7 & 0 \\
\hline & UA & 7,8 & 27,5 & 50 & 9,4 & 5,3 \\
\hline \multirow[t]{3}{*}{ Régiójával } & $\mathrm{HU}$ & 3,7 & 14,6 & 46,9 & 21,6 & 13,2 \\
\hline & PL & 4,6 & 25,9 & 51,3 & 18,1 & 0 \\
\hline & UA & 9 & 26 & 48,5 & 9,7 & 6,9 \\
\hline \multirow[t]{3}{*}{ Európával } & $\mathrm{HU}$ & 7,1 & 18,7 & 31,7 & 28 & 14,4 \\
\hline & $\mathrm{PL}$ & 6,9 & 26,2 & 44,4 & 22,5 & 0 \\
\hline & UA & 10,8 & 15,5 & 44,2 & 21,2 & 8,2 \\
\hline \multirow{3}{*}{$\begin{array}{l}\text { Saját etnikai } \\
\text { csoportjával }\end{array}$} & $\mathrm{HU}$ & 24,4 & 33,7 & 17,7 & 4,8 & 19,4 \\
\hline & $\mathrm{PL}$ & 4,4 & 20,1 & 57,4 & 18,1 & 0 \\
\hline & UA & 12,7 & 32,1 & 32,1 & 12,5 & 10,6 \\
\hline
\end{tabular}

Forrás: Youth in the Central and Eastern European Crossborder Areas 2015 adatbázis

1. számú táblázat: Mennyire érzi erősnek a kapcsolatát a felsorolt közösségekkel? (százalék, HU N=359, PL N=413, UA, $N=468^{4}$ )

\footnotetext{
${ }^{3}$ Szerbia területe.

${ }^{4}$ HU Magyarország; PL Lengyelország, UA Ukrajna
} 
A nemzetközi kutatás az említett kutatáshoz hasonlóan a közösségekre kérdezett rá, melyet a különböző terekkel, területi nagyságokkal köt össze (lásd 1. táblázat). Így a diákok kapcsolatát különböző közösségekkel (mint pl.: ország állampolgáraival, családdal, városával, megyéjével, régiójával, stb.), zárt kérdésekkel tudakoltuk. A közösség fontosságát négy fokú skálán értékelhették, arra is lehetőségük volt, hogy egyik felkínált közösséget se értékeljék, ha azzal kapcsolatban semmit sem gondoltak, illetve nem akartak válaszolni.

A lengyel fiatalok jelölték a legerősebbnek a kapcsolatukat az országukkal $(67,7 \%)$, míg a magyar fiatalok csupán egynegyede $(26,9 \%$-a) jelölte meg nagyon erősnek, illetve erősnek e kapcsolatot, mely eltér Magyar Ifjúság Kutatás 2016-os eredményeitől. Különbség mutatkozik az országok fiataljainak válasza között más földrajzi téregység esetében is. E témakör vizsgálata fontos lehet abban, hogy megismerjük, hogy a városával (falujával) való kapcsolat, elégedettség, hogyan befolyásolhatja a fiatalokat a helyben maradásban. A lengyel és az ukrán fiatalok a magyar fiataloknál szorosabban kötődnek a településeikhez, régiójukhoz és Európához. A lengyel és az ukrán fiatalok kötödése a szakirodalommal megegyező ${ }^{5}$, a diákok kötődése a városhoz erősebb, mint az etnikumhoz és az elvontabb földrajzi fogalomhoz.

Az elemzések során hasonlóságok is mutatkoznak abban, hogy a fiatalok nemzetiségtől függetlenül „gyengének”, illetve „,egyáltalán nem érez” kapcsolatot a megyéjével. További hasonlóság, hogy a megkérdezett $(\mathrm{N}=1240)$ diákból a nemzetiségüktől függetlenül, több mint $90 \%$-a azt jelölte be, hogy a családdal nagyon erősnek, illetve erősnek érzi a kapcsolatát. Azt a tényt, hogy a fiatalok pozitívan viszonyulnak a családjaikhoz, más empirikus ifjúsági vizsgálat (Magyar Ifjúság Kutatás 2016, R. Fedor, 2016) is alátámasztja.

A vizsgálatnak a saját etnikai csoportjával kapcsolatos kötödés eredményét a szakirodalommal összevetve azt állapíthatjuk meg, hogy alacsonyabb százalékban jelölték meg erősnek a diákok saját etnikai csoportjával való kötődésüket. A mi vizsgálatunk során a magyar fiatalok jelölték a legnagyobb arányban (24,4\%-a), hogy nagyon erős a kötödésük és 33,7\%-a a megkérdezetteknek erősnek jelölte meg a kapcsolatot a saját etnikumával. Ezzel ellentétben a lengyel fiatalok jelölték a legkisebb százalékban nagyon erősnek, illetve erősnek a kapcsolatát a saját etnikumával. Az eredmény figyelemre méltó: a magyar fiatalok körében az országhoz való kötődés alacsonyabb, míg az etnikumhoz való kötődés magasabb. Elsődleges feltételezésünk az volt, hogy az etnikai hovatartozás fontossága inkább a lengyel és az ukrán fiatalok körében lesz magasabb és az országhoz való kötödés alacsonyabb, mint a magyaroké. E feltételezésünket a lengyel és ukrán nemzetállam kialakulására és történelmi múltjára alapoztuk, valamint a határmentén lakók színes etnikumú összetételére.

A Ristić és társai (2013) kutatás eredménye nem összehasonlítható, de párhuzamba vonható és megállapítható a jelen kutatás során is, hogy a magyarok esetében

\footnotetext{
${ }^{5}$ Magyarországon Egedy (1996) végzet empirikus vizsgálatot három városban (Győr, Szarva és Budapest), a kutatása során első kérdése az volt, hogy elégedett-e a diák a városával. A győri fiatalok döntő többsége (89\%) elégedett, szarvasi fiatalok magas aránya (83\%) elégedett, míg Budapesten jelentősen megoszlik a diákok véleménye a megkérdezettek $70 \%$-a mondott igent a kérdésre.
} 
a saját etnikai csoporthoz tartozás a kutatott ifjúság körében fontosabb, mint a lakóhely, megye, régió, ország és Európához való kötődés. Ennek ellenére a vizsgálat feltűnő eredménye az, hogy a magyar megkérdezettek ötöde (19,4\%-a) nem tudott mit kezdeni az etnikai kérdéssel, illetve nem akart válaszolni a kérdésre. Fontos megemlíteni, hogy a „nem tudom és nem válaszolok” válaszok a legnagyobb százalékban, a többi kérdéskör esetében is a magyar válaszadók körében fordult elő leggyakrabban. Célszerü lett volna a kérdőív szerkesztésekor e két válaszlehetőséget elkülöníteni egymástól.

Az elvárások mérése, melyek a jövő felé irányulnak alkalmasak a regionális öntudat mérésére. „A régió identitása „szubjektív” és „objektív” részre is osztható. Az előbbi azokra az elképzelésekre utal, amelyekkel: 1. az ott lakók és 2. a régión kívül élök rendelkeznek az adott régióról. A második pedig azokra az osztályozásokra vonatkozik, amelyeket különböző diszciplinák képviselői kutatási eredményként alakítottak ki, pl. olyan regionális felosztások, amelyek a természeti környezetre, kultúrára, tájakra stb. épülnek" (Paasi, 1989:77-78). Így e nemzetközi kutatás a térséghez való viszonyulás témakörét elsőként a kérdőíves vizsgálat segítségével úgy operacionalizálta, hogy rákérdezett a véleményükre: szerintük a régiójukban a fiataloknak van-e lehetősége elérni céljaikat. Hat válaszlehetőség volt adott (igen, van; inkább nincs; van is, meg nincs is; inkább nincs; nincs; nem tudom/nem válaszolok). A megkérdezettek (lásd. 2. táblázat) közel fele $(44,6 \%)$ igen van, inkább van választ adták.

\begin{tabular}{|c|c|c|c|c|c|c|c|}
\hline $\begin{array}{c}\text { Célok elérésének } \\
\text { lehetősége a régió- } \\
\text { ban }\end{array}$ & \multirow[t]{2}{*}{$\begin{array}{l}\text { Igen, } \\
\text { van }\end{array}$} & \multirow[t]{2}{*}{$\begin{array}{c}\text { Inkább } \\
\text { van }\end{array}$} & \multirow[t]{2}{*}{$\begin{array}{c}\text { Van is, } \\
\text { meg } \\
\text { nincs is }\end{array}$} & \multirow[t]{2}{*}{$\begin{array}{c}\text { Inkább } \\
\text { nincs }\end{array}$} & \multirow[t]{2}{*}{ Nincs } & \multirow[t]{2}{*}{$\begin{array}{l}\text { Nem tudom, } \\
\text { nem válaszo- } \\
\text { lok }\end{array}$} & \multirow[t]{2}{*}{ Missing } \\
\hline Országok & & & & & & & \\
\hline $\begin{array}{l}\text { Magyarország } \\
(\mathrm{N}=359)\end{array}$ & 15,9 & 10,6 & 47,9 & 13,9 & 8,9 & 1,1 & 1,7 \\
\hline $\begin{array}{l}\text { Lengyelország } \\
(\mathrm{N}=411)\end{array}$ & 9,0 & 30,7 & 21,4 & 21,2 & 7,8 & 10,0 & 0,0 \\
\hline Ukrajna $(\mathrm{N}=468)$ & 29,3 & 33,5 & 11,3 & 13,0 & 3,8 & 8,1 & 0,9 \\
\hline Összesen $(\mathrm{N}=1238)$ & 18,7 & 25,9 & 25,3 & 16,0 & 6,6 & 6,7 & 0,8 \\
\hline
\end{tabular}

Forrás: Youth in the Central and Eastern European Crossborder Areas 2015 adatbázis

2. táblázat: Célok elérésének lehetősége a régióban a fiatalok körében (százalék)

Az országok közül Ukrajna fiatalsága adta a legpozitívabb választ erre a kérdésre, 62,8\%-a ,igen van” és „inkább van lehetőségük” a határmenti régiójukban a céljaik elérésében. Ami talán azzal is magyarázható, hogy az ukrán fiatalok jobban kihasználják a határrégió adottságait (lásd 3. táblázat). Ami nem más, mint a határon átnyúló rokoni és baráti kapcsolatok, a munkavállalás, tanulás, gazdasági vagy szabadidő-eltöltési tevékenység. Fontos megemlíteni, hogy a vizsgálat célja az volt, hogy a diákok az adott várossal szomszédos régiók országaival kapcsolatban fogalmazzanak meg állítást. Vélhetőleg a fiatalok ezt nem minden esetben vették figyelembe az 
eredmények alapján következtethetünk erre. Nehezen hihető ugyanis, hogy pl. a nyíregyházi diákok közel egyharmada Ukrajnában, Szlovákiában vagy Romániában akarna letelepedni, ugyanígy az is, hogy $40 \%$ beszélné ezen országok nyelvét. A kutatás nem tért ki arra, hogy a megkérdezett diákok honnan érkeztek (p. Kárpátalja, Erdély, stb.)

\begin{tabular}{|l|c|c|c|c|c|c|}
\hline Országok & \multicolumn{2}{|c|}{$\begin{array}{c}\text { Magyarország } \\
(\mathrm{N}=358)\end{array}$} & \multicolumn{2}{c|}{$\begin{array}{c}\text { Lengyelország } \\
(\mathrm{N}=412)\end{array}$} & \multicolumn{2}{c|}{$\begin{array}{c}\text { Ukrajna } \\
(\mathrm{N}=453)\end{array}$} \\
\hline $\begin{array}{l}\text { Szomszédos országokban végzett } \\
\text { tevékenység és terv: }\end{array}$ & Igen & Nem & Igen & Nem & Igen & Nem \\
\hline Bevásárlás & 21,2 & 77,7 & 17,7 & 82,3 & 47,7 & 51,4 \\
\hline Szülei dolgoznak ott & 7,3 & 91,6 & 7,5 & 92,5 & 27,5 & 71,4 \\
\hline Rokoni kapcsolat & 37,2 & 61,7 & 33,3 & 66,7 & 58,4 & 40,7 \\
\hline Baráti kapcsolat & 50,3 & 48,3 & 30,7 & 69,3 & 42,2 & 50,9 \\
\hline $\begin{array}{l}\text { Tartja a szomszédos országok ün- } \\
\text { nepségét }\end{array}$ & 16,8 & 82,1 & 6,8 & 93,2 & 31,1 & 68,0 \\
\hline Gyakran jár a szomszédos országokba & 20,4 & 78,5 & 12 & 88 & 29,5 & 69,4 \\
\hline $\begin{array}{l}\text { Tervezi tanulmányai folytatását } \\
\text { valamely szomszédos országban }\end{array}$ & 20,4 & 78,2 & 4,6 & 95,4 & 34,8 & 64,1 \\
\hline $\begin{array}{l}\text { Tervez letelepedni a szomszédos } \\
\text { országok valamelyikében }\end{array}$ & 29,9 & 68,4 & 7,5 & 92,5 & 45,6 & 53,3 \\
\hline $\begin{array}{l}\text { Beszéli a szomszédos országok va- } \\
\text { lamelyikének nyelvét }\end{array}$ & 38,5 & 60,3 & 23,1 & 76,9 & 52 & 47,1 \\
\hline
\end{tabular}

Forrás: Youth in the Central and Eastern European Crossborder Areas 2015 adatbázis

3. táblázat: Fiatalok határon átívelő tevékenységeik és terveik (százalék)

Ha tüzetesebben megvizsgáljuk a kapott válaszokat, akkor láthatjuk, hogy a vizsgált három nemzet fiataljai különböző mértékben használják ki a határrégiói lehetőségeiket A khí-négyzet próba segítségével megállapítható, hogy adott állampolgárság és a kérdésre adott válaszok közötti összefüggés nem tekinthetö függetlennek. A magyarok a legnagyobb százalékban (50,3\%) igenlö választ arra adták, hogy baráti kapcsolattal rendelkeznek a szomszédos országok valamelyikében, illetve hogy rendelkeznek rokoni kapcsolattal, valamint beszélik a szomszédos országok valamelyik nyelvét. Az ukrán fiatalok, még a magyar fiataloknál is több igen választ adtak a megkérdezett témában, 58,4\%-nak élnek rokoniak, közel fele jár bevásárolni és 45,6\%-a tervez letelepedni a szomszédos országok valamelyikében. Ami sok tényezővel is magyarázható: elsőként a Kelet-ukrajnai háború miatt a fiatalok kivándorolnak, másik fő ok a gyenge gazdasági helyzet. A lengyel megkérdezettek határon átívelö szokásaik, kapcsolataik, illetve terveik kis százalékban jelennek meg, csak 4,6\%-uk tervez tanulmányt folytatni és 7,5\%-uk tervez letelepedni a szomszédos országok valamelyikében, holott 33,3\%-uk rendelkezik rokoni 
kapcsolattal és $23,1 \%$-a beszéli a szomszédos országok valamelyik nyelvét. Az alacsony százalékos adatok várhatóak voltak, mivel a keleti régió fiataljai számára kevésbé vonzóak a szomszédos régiók, országok (Ukrajna, Fehéroroszország).

\section{Határmenti megye és a szomszédos nemzetek}

A határmenti területek jelentőségével és dimenzióival számos regionalista foglalkozott (Baranyai, 2004; Rechnitzer, 1997; Hardi, 2001, 2002, 2008). A határ önmagában hordoz másságot és egyediséget, minden határterület más-más gazdasági, nemzeti, politikai, kapcsolati, intézményi és térszerkezeti rendszerrel rendelkezik. Ezek az adottságok elősegíthetik vagy gátolhatják az adott lakosság megélhetését. A határmentiség jellemzője az is, hogy határon átnyúló rokoni és baráti kapcsolatok, a munka, tanulás vagy szabadidő-eltöltési célú határátlépés a mindennapok velejárója (Hardi, 2008). A vizsgálatunk során arra voltunk kíváncsiak, hogy a fiatalok mennyire érzik a határmentiség hatását az életükre (lásd. 4. táblázat). Zárt kérdés során öt válasz lehetőséget biztosítottunk (igen, hatással van; többnyire hatással van; van amiben van hatással, van amiben nincs; többnyire nincs hatással; egyáltalán nincs hatással).

\begin{tabular}{|l|c|c|c|c|c|}
\hline $\begin{array}{l}\text { Kérdés válasz } \\
\text { lehetőségei }\end{array}$ & $\begin{array}{c}\text { igen, } \\
\text { hatással } \\
\text { van }\end{array}$ & $\begin{array}{c}\text { többnyire } \\
\text { hatással van }\end{array}$ & $\begin{array}{c}\text { van amiben hatás- } \\
\text { sal van, van ami- } \\
\text { ben nincs hatással }\end{array}$ & $\begin{array}{c}\text { többnyire } \\
\text { nincs } \\
\text { hatással }\end{array}$ & $\begin{array}{c}\text { egyáltalán } \\
\text { nincs hatással }\end{array}$ \\
\hline $\begin{array}{l}\text { Magyarország } \\
(\mathrm{N}=354)\end{array}$ & 11 & 11,3 & 29,9 & 22,9 & 24,9 \\
\hline $\begin{array}{l}\text { Lengyelország } \\
(\mathrm{N}=409)\end{array}$ & 20 & 15,6 & 26,4 & 28,9 & 9 \\
\hline $\begin{array}{l}\text { Ukrajna } \\
(\mathrm{N}=448)\end{array}$ & 38,6 & 15 & 28,8 & 9,2 & 8,3 \\
\hline
\end{tabular}

Forrás: Youth in the Central and Eastern European Crossborder Areas 2015 adatbázis

4. számú táblázat: A határmenti megye hatással van az Ön életére? (százalék, N=1211)

A magyar fiatalok 11\%-a érzi, hogy hatással van az életére, míg az ukrán fiatalok 38,6\%-a érzi e hatást, ami magyarázható ismét az ukrán háborús helyzettel. A magyar és a lengyel fiatalok hasonló válaszokat adtak a „többnyire hatással van”, „van, amiben hatással van amiben nincs” és a „többnyire nincs hatással”. A magyar fiatalok ,egyáltalán nincs hatással” válaszaik kiugróan magasak (24,9\%) a lengyelekhez (9\%) és az ukránokhoz (8,3\%) viszonyítva. Megvizsgáltuk regresszió elemzéssel, hogy ezeket az eltérő válaszokat milyen változók befolyásolják. Független változók voltak: ország, nem, hol él a családja (település típus), apja és anyja iskolai végzettsége és beosztásuk, a család szubjektív anyagi helyzete. A vizsgálat során megállapíthatjuk, hogy az ország és a család szubjektív anyagi helyzete szignifikáns hatással van $\left(\mathrm{Sig}=0,000 \mathrm{p} \leq 0,05, R^{2}=0,036\right)$, gyenge pozitív a kapcsolat. Koefficiensek tpróbájának szignifikancia szintje alapján döntöttük el, hogy csak e két magyarázó változó maradhat. F-próba szignifikancia szintje 0,000 volt, azaz szignifikáns. A standardizált koefficiens beta száma alapján a két változó közül a szubjektív anyagi 
jólét befolyásolja erőteljesebben a határmenti megye hatásainak érzékelését. Továbbá megvizsgáltuk azt is, hogy beszéli-e a szomszédos országok valamelyik nyelvét, vagy nem, e között találhatunk szignifikáns eltéréseket. Fontos a nyelvismeretnél kiemelni, hogy a vizsgált fiatalok $(\mathrm{N}=1188)$ 38,2\%-a azt jelölte meg, hogy beszéli a szomszédos ország nyelvét annak ellenére, hogy nem nemzetközi nyelvekről van szó A kapott válaszok a hétköznapi tapasztalatoknak ellent mondanak, mely további vizsgálatot érdemelne. Az elemezések során azt az eredményt is kaptuk, hogy a válaszadók minél jobb anyagi körülmények között élnek, illetve beszélik a szomszédos ország nyelvét, annál jobban érzik a határmentiség kihatását az életükre. Továbbá az is megfigyelhető, hogy a szomszédos országokban végzett aktivitás (bevásárlás, szülök munkavégzése, rokon és barátok, tanulmány folytatás tervezése, letelepedés tervezése, szomszédos nyelvismeret) ugyancsak szignifikáns (Khí2 p=0,00) különbséget mutat a határmenti hatás megítélésben.

$\mathrm{Az}$ ifjúság határmenti térségi identitásának, illetve a határmentiség hatásának megismeréséhez fontos feltárni a fiatalok szomszédos országban végzett tevékenységét, e tevékenységek gyakoriságát (lásd 5. táblázat).

\begin{tabular}{|l|c|c|c|c|}
\hline $\begin{array}{l}\text { Kérdés válasz } \\
\text { lehetőségei }\end{array}$ & $\begin{array}{c}\text { havonta né- } \\
\text { hányszor }\end{array}$ & $\begin{array}{c}\text { évente néhány- } \\
\text { szor }\end{array}$ & $\begin{array}{c}\text { egyszer-kétszer } \\
\text { életemben }\end{array}$ & $\begin{array}{c}\text { még nem } \\
\text { jártam }\end{array}$ \\
\hline $\begin{array}{l}\text { Magyarország } \\
(\mathrm{N}=350)\end{array}$ & 6,6 & 42,6 & 39,1 & 11,4 \\
\hline $\begin{array}{l}\text { Lengyelország } \\
(\mathrm{N}=408)\end{array}$ & 2,2 & 32,4 & 47,1 & 18,4 \\
\hline $\begin{array}{l}\text { Ukrajna } \\
(\mathrm{N}=459)\end{array}$ & 17,2 & 24 & 22 & 36,8 \\
\hline
\end{tabular}

Forrás: Youth in the Central and Eastern European Crossborder Areas 2015 adatbázis

5. táblázat: Milyen gyakran szokott külföldön járni (\%)

A megkérdezettek $(\mathrm{N}=1217)$ többsége volt már külföldön életében, 9,1\%-a havonta néhányszor, 32,1\%-a évente néhányszor, 35,3\%-a egyszer-kétszer volt már életében és 23,3\%-uk még nem járt külföldön. A havonta néhányszor, évente néhányszor és egyszer-kétszer voltam életembe adott válaszokat összevontuk arra, hogy „,volt már külföldön”, valamint külön válaszként kezeltük, hogy „még nem voltam”. A ,volt már külföldön" válaszadó válaszait megvizsgáltuk, hogy milyen célból voltak külföldön; a leggyakrabban a következő célból: 71,2\%-a turizmus, 5,5\%-a üzleti út - ami alatt áru eladását vagy vételét kell érteni - és 13,7\%-uk rokonok és barátok látogatása céljából. A külföldi utazás gyakorisága szoros összefüggésben áll a család szubjektív jólétével, valamint az apa és az anya iskolai végzettségével.

A határmentiség vizsgálatakor fontos figyelembe vennünk, hogy a fizikai térben létező határok mellett nagy jelentősége van a tudatunkban képződő mentális határoknak is, mivel a politikai határok létét erősíthetik vagy gyengíthetik. „A mentális határ fogalom alatt azt a képzeletbeli vonalat értjük, mely egyes ember területi identitásának végső földrajzi pontjait köti össze, s amelyen belül élőket még a „mi” csoportjába, s a rajta kívül élőket az „ők” csoportjába sorolja, tehát egy pszichikai távolság térbeli leképzése” (Hardi, 2002: 2). A határ másik oldalán élőkről kialakított 
kép befolyásolja a két népcsoport közötti viszonyt. A kérdőívben egy kérdés különböző nemzeteket (lengyel, német, amerikai, orosz, litván, fehérorosz, román, ukrán, szlovák, cseh, francia, muszlim népek) sorakoztat fel és azt vizsgálja, hogy a megkérdezett hogyan viszonyul e nemzetekhez. A három nemzet fiataljait külön-külön vizsgálva megállapíthatjuk, hogy hasonlóság mutatkozik a társadalmi távolság érzet tekintetében. A lengyel, magyar és az ukrán fiatalok a legpozitívabb viszonyulást az amerikai, francia és német nemzettel szemben mutattak, és a negatív viszonyulást a muszlimokkal szemben tanúsítottak. Meglepő, hogy minden ország fiataljai a muszlimokkal megegyezően negatívan ítélték a viszonyulásukat a szomszéd országok egyikéhez. A magyar fiatalok negatívan viszonyulnak a román nemzethez, a lengyelek és az ukránok pedig az orosz nemzethez. Más nemzethez való viszonynál meghatározó, hogy milyen ismeretekkel, képekkel és generációs tapasztalatokkal rendelkezünk, valamint milyen történelmi múltba ágyazódik a nemzeti kapcsolatunk.

Magyarázó változók (szülők iskolai végzettsége, nem és szubjektív jólét) segítségével próbáltuk feltárni, hogy e negatív és nagyarányú „nehéz egyértelmű választ adni" válaszok mivel vannak összefüggésben. A vizsgálat során nem találtunk összefüggéseket $(\mathrm{p} \leq 0,005)$ a nemzetiségekhez való viszonyulásra kapott válaszok és a magyarázó változókra adott válaszok között. Azt is megvizsgáltuk, hogy a megkérdezettek nemzetiséghez való viszonyulását befolyásolja e, hogy beszéli-e, vagy nem a szomszédos ország nyelvét, illetve rendelkezik-e, vagy nem rokoni, baráti kapcsolatokkal, valamint, hogy milyen gyakran ,jár át a szomszédos országokba”. Azt az eredményt kaptuk, hogy e tényezők nem befolyásolják a szomszédos nemzetekhez való viszonyulásukat. Továbbá azt is megállapíthatjuk, hogy a diákok a nemzetiségekkel szemben tanúsított attitüdjeik alapján kevésbé elfogadók.

\section{Összegzés}

A 2015-ben 11-12. évfolyamos kelet-európai diákok (N=1240) körében végzett kérdőíves felmérésünk adatainak elemzése rávilágít a magyar, lengyel és az ukrán fiatalok regionális, lokális identitására, külföldi tapasztalataira, terveire, mobilitás vágyára.

A kutatás alapján megállapíthatjuk, hogy a lokalitásnak nagy szerepe van a fiatalok identitáskonstrukciójában. A három ország fiataljai identitástudata eltérő: míg a lengyelt az országához nagyon erős kötelék füzi, addig a magyart gyenge vagy egyáltalán nem füzi kötelék országához. A megkérdezett diákokat a családjukhoz és a saját etnikai csoportjukhoz füzi a legerősebb kötelék. Ugyanakkor a három ország fiataljainak véleményében vannak közös jellemzők is, ilyen például, hogy a családhoz hasonlóan erös kapcsolat füződik, valamint hasonlóan gyenge vagy egyáltalán nem füződik kapcsolatuk a megyékhez, régiókhoz és Európához. Meglepő eredmény, hogy a megkérdezettek szomszédos országokkal lévő kapcsolata nem befolyásolja a szomszédos nemzethez füződő viszonyulásukat, holott a vizsgált diákok erős regionális kapcsolatát jelzi, hogy a szomszédos országokban sok barátjuk, rokonuk él, gyakran járnak a szomszédos országokba. Általánosságban az utazási tapasztalatokat tekintve azt látjuk, hogy a szakirodalomban jellegzetes mintázatok rajzolódtak ki a vizsgált középiskolások mintájában is: a magasabb szocio- 
ökonómiai státuszú fiatalok jártak már többször külföldön. A más népek iránti attitüdjeik, s a preferencia-sorrend is hasonló, mint a korábbi országos ifjúságvizsgálatokban. A társadalmi-távolság érzését befolyásolja a szülők iskolai végzettsége, $\mathrm{s}$ a család gazdasági helyzete is: a jobb helyzetű családok gyermekei pozitívabban vélekednek más nemzetekről. A vizsgált fiatalok nemzetközi mobilitási tervei hasonló trendeket mutatnak, mint más ifjúságkutatások. A markánsan megfogalmazódó tanulási tervek alacsonyak, azonban a külföldi migrációs tervek (munkavállalási, letelepedési céllal) már magasabb arányban jelennek meg, viszont a mobilitási tervek mögött meghúzódó háttérváltozók nem egyértelmüek.

Végezetül megállapíthatjuk, hogy annak ellenére, hogy a diákok regionális, megyei identitása alacsony, mégis látnak esélyt a céljaik elérésére, valamint belátják, hogy hatással van rájuk a határ menti megyéjük. E területi identitástudatot szükséges lenne fejleszteni és gazdasági tevékenységre felhasználni, mivel a diákoknak miden rendelkezésükre áll: pl. rokoni-baráti kapcsolatuk van, nyelv és kultúra ismerettel rendelkeznek.

\section{Hivatkozott irodalom}

1. Baranyi B. (2004): Gondolatok a perifériaképződés történeti előzményeiről és következményeiről. Tér és Társadalom 18 (2) 1-21.

DOI: 10.17649/TET.18.2.942

2. Blotevogel, H.H.-Heinritz, G.-Popp, H. (1989) „Regionalbewusstein" - Zum Stand der Diskussion um einen Stein Anstosses. - Geographische Zeitschrift. 2. 65-88. o.

3. Bőhm A. (2000): Térségi identitás. - Horváth Gy.-Pálné Kovács I. (szerk.) Területfejlesztés és közigazgatás-szervezés. MTA, Budapest. 111-127. o.

4. Csepeli Gy. (1997): Szociálpszichológia. Budapest, Osiris Kiadó.

5. Egedy T. (1996): A város és az ifjúság - Budapest, Győr és Szarvas a fiatalok szemével. Tér és Társadalom 10 (2-3). 43-54.

6. Hardi T. (2001): Az egységes határrégiók kialakulásának feltételei - lehetséges határrégiók a Kárpát-medencében. Doktori értekezés, PTE KTK, Győr-Pécs.

7. Hardi T. (2002): Néhány földrajzi elmélet alkalmazása a Kárpát-medence határtérségeire és a határ menti együttmüködéseire. In: Dormány G és társ. (szerk.) A földrajz eredményei az új évezred küszöbén [Elektronikus dokumentum]: A Magyar Földrajzi Konferencia tudományos közleményei: Szeged, 2001. október 2527. Szegedi Tudományegyetem TTK Természeti Földrajzi Tanszék,1-15.

8. Hardi T. (2008): A határtérség térszerkezeti jellemzői. Tér és Társadalom 22 (3). 3-25. DOI:10.17649/TET. 22.3.1183

9. Ilyés Z. (2004): A határforgalom változó tartalmai a geográfiától az empirikus kultúra kutatásig. In: Kovács, N. et al (eds.), Tér és terep. Tanulmányok az etnicitás és az identitás kérdésköréből III. (9-15). Budapest: Akadémia Kiadó.

10. Ludescher G. (2009): Kistérség és identitástudat. Egy kutatás tapasztalatai. Területfejlesztés és innováció 3 (4). 23-28. 
11. Murányi I.; Szoboszlai, Zs. (2000): Identitás - jellemzők a dél-alföldi régióban. Tér és társadalom 14 (1). 27-49. DOI: 10.17649/TET.14.1.556

12. Murányi I.; Szabó, I. (2007): Középiskolások előítéletességének egy lehetséges magyarázata: az életforma. Educatio (1). 38-49.

13. Murányi I. (2012): Előítéletesség és demokrácia-értelmezés a fiatalok körében. Educatio (2). 259-271.

14. Nárai M. (2009): Gondolatok a regionális identitásról - identitáselemek a nyugat-dunántúli régióban. Tér és Társadalom 23 (4). 137-159.

15. Paasi A. (1989): A régiók fejlődése és a regionális identitás kialakulása. Tér és társadalom 3 (3). 70-79.

16. Paasi, A. (2003): Region and Place: regional identity in question. - Progress in Human Geography. 4. 475-485. o.

17. Palkó K. (2009): Mesterségesen létrehozott területi egység - regionális identitás (?) Burgerland példája. Tér és társadalom 23 (4). 207-224.

18. Pusztai G.; Nagy, É. (2005): Tanulmányi célú mobilitás Magyarország keleti határvidékein. Educatio (2). 360-384.

19. R. Fedor A. (2016): Családalapítás és gyermekvállalás a fiatalok körében. Acta Medicinae et sociologica 7 (20-21). 11-28.

20. Raagmaa, G. (2002): Regional identity in Regional Development and Planning. - European Planning Studies. 1. 55-76.

21. Rechnitzer J. (1997): Eurorégió-vázlatok a magyar-osztrák-szlovák határmenti térségben Tér és Társadalom 11 (2). DOI: 10.17649/TET.11.2.419

22. Ristić, D.; Nagy, I.; Kicošev, S. (2013): „Hely” és identitás. Egy temerini középiskolások körében végzett vizsgálat tanulságai. Tér és Társadalom 27 (2). 159-170.

23. Somlyódiné Pfeil E. (2007): Mozaikok a regionális identitás értelmezéséhez. Tér és Társadalom 21. (4). 57-71.

24. Strassoldo R. (1990): The social construction and sociologic alanalysis of space. In: Hamm, B.; Jalowiecki, B. (eds.), The social nature of space. Polish Academy of Sciences, Committee for Space Economy and Regional Planning (19-49). Warszawa.

25. Süli-Zakar I. (2010): A Partium régió esélyei a csatlakozás után. In: Juhász, E. (ed.), Régió és oktatás V. Harmadfokú képzés, felnőttképzés és regionalizmus. (15-24). Debrecen: Center for Higher Education Research and Development (CHERD). 